\title{
Compilation and Testing the Reliability of Questionnaires about the Fear of Blood Extraction (Venipuncture) among Students of Medical Faculty of Kragujevac
}

\author{
Suzana Milutinović ${ }^{1}$, Ana Stanković2, Sunčica Ivanović ${ }^{1}$, Sanja Trgovčević1, \\ Tatjana Kilibarda ${ }^{1}$ \\ ${ }^{1}$ College of Applied Health Sciences Cuprija, Ćuprija, Serbia \\ ${ }^{2}$ Faculty of Medical Sciences in Kragujevac, Kragujevac, Serbia
}

SUMMARY

It is of particular importance to use validated questionnaires to remove fear of needles and blood collection, as this public health problem has been observed in a large number of patients and may inadequately affect medical healthcare.

The aim of the study was to conduct a research on the reliability of the questionnaire on the fear of blood sampling among students of the Faculty of Medical Sciences in Kragujevac.

The method used in this research was a cross-sectional study. The sample involved the students of medicine, pharmacy, dentistry and professional studies of health care at the Faculty of Medical Sciences in Kragujevac (Republic of Serbia), a total of 300 students, which was $20 \%$ of the student population at the aforementioned faculty. The research instrument was the questionnaire The Blood-Injection Symptom Scale (BISS) which contained 22 questions. The research lasted one month during 2016. Statistical data processing was performed using IBM SPSS Statistics 21.

Cronbach's Alpha value - 0.894 and other parameters used to determine reliability showed a high reliability of this questionnaire. After explorative factor analysis, three factors that most affect adverse outcomes for venepuncture were obtained -vasovagal symptoms that occur as a result of fear, fear of needles and consequences of puncture, and the fear of hospitals and personnel who take blood samples.

The BISS questionnaire showed good reliability in the population of students of the Faculty of Medicine in Kragujevac and can be used in the general population for examining the fear of needles, the consequences of needle stings, fear of hospitals and people who take blood samples, and therefore to prevent these symptoms.

Key words: questionnaire, reliability, fear of needles and blood collection

Corresponding author:

Sunčica Ivanović

e-mail: suncica.ivanovic@yahoo.com 


\section{INTRODUCTION}

A large number of patients who receive medical help have blood-injection-injury phobia (3.5\% of them) (1). This phenomenon can pose a significant problem during the provision of otherwise frequent health care services, such as blood collection or parenteral administration of medications. Among many of them, fear can be so intense that such people are diagnosed with phobia (blood-injection-injury phobia), which according to the definition of the American Association of Psychiatrists is characterized by excessive and irrational fears which are initiated by expectation or the presence of a specific object or situation. Fear of blood collection has many different manifestations. It is described in people who are greatly afraid when exposed to blood (homophobia fear of blood) or to medical procedures involving blood, injections (trypanophobia), or invasive medical procedures (2). There are significant physiological reactions among patients when they consider blood extraction, which is manifested by their avoidance of important medical procedures, from ordinary examinations to surgeries (3).

This phobia is characterized by strong vasovagal reaction which is biphasic. The first phase is characterized by the activation of sympathetic nervous system (SNS) on the basis of fight or flight phenomenon. The second phase is characterized by the activation of SNS which leads to the loss of consciousness, followed by the feeling of disgust. In the root of this phobia is a disorder of the autonomic nervous system regulation, which creates a predisposition for the emergence of syncope (4 - 6).

The study "The mutilation questionnaire as a predictor of blood/injury fear and fainting", which is about the reliability of a questionnaire on a similar topic, was conducted on two groups of students (the first group included 803 and the second 204 undergraduate students). Three different questionnaires were used in this study to identify the students who experienced the loss of consciousness in situations involving blood and needles, i.e. fear of sharp objects, human and animal blood and a dead body. The questions were classified into two groups - disgust due to blood, injury and mutilation, and fear of bodily injury, although the values of the exploratory analysis indicated a greater number of factors (2).

In the study "The blood-injection symptom scale (biss): assessing a structure of phobic symp- toms elicited by blood and injections", 605 students of Psychology participated, of average age of 19 years, and by exploratory factor analysis three factors were identified that were related to the symptoms in this phobia: weakness, anxiety, and tension. All three factors were related to the symptoms that subjects may experience during blood sampling, and did not include questions related to fear of a needle, hospital, or blood sampling staff. The disadvantage of this questionnaire was that the offered answers were either yes or no, and it was impossible to include all respondents with this phobia (7).

A study conducted in Spain (Blood-injection Phobia Inventory (BIPI): Development, reliability and validity) included 39 patients between 15 and 30 years of age, who were diagnosed with fear of blood and needles according to the DSM-IV classification, as a specific phobia and no other phobias or anxiety disorder detected, and a control group of 137 subjects from the general population. The Fear Questionnaire used in this study was designed to measure agoraphobia, social phobia and BII phobia, and it was made of two parts (the first one refers to the level to which individuals avoid certain situations and events related to these phenomena and the answers offered in the form of the Likert scale; the second part of the questionnaire addresses their concern for the presence of the symptoms of anxiety, fear and depression).

This study elaborates three factors: cognitive, psychological, and behavioral response to fear.

This questionnaire shows a high reliability (values of the questionnaire in total $\alpha=0.78$; BII phobia $-\alpha=0.75$; social phobia $-\alpha=0.64$; agoraphobia $-\alpha$ $=0.55$ ).

Compared to previous studies, this one has a greater advantage and significance, and with the best approach measures the examined phenomenon in the control and experimental group. The disadvantage of this study is the size of the tested sample, and a slightly lower value of the Cronbach's alpha parameter (8).

The Blood-Injection Symptom Scale (BISS) the BISS (Page, Bennett, Carter, Smith \& Woodmore, 1997) is a questionnaire with 17 questions which include assessing a structure of the phobic symptoms elicited by blood and injections. The reliability of this questionnaire is $\alpha=0.86$ (7).

A 2014 study conducted in India aimed to determine the prevalence of feelings of fear of veni- 
puncture in female subjects. Respondents were asked to complete a questionnaire of 21 questions. The reliability of this questionnaire was $\alpha=0.9$ (9).

These questionnaires have high reliability, but they include claims that are more related to the very thought of blood, needle or injuries, and fewer ones are specifically related to blood extraction and possible consequences, which can be the cause of fear in the general population.

Therefore, the aims of this study are to test the reliability of the questionnaire concerning the fear of blood extraction among students of the Faculty of Medical Sciences at the University of Kragujevac (Republic of Serbia), and to review some occurrences in patients undergoing venepuncture, which had not been covered by previous questionnaires.

\section{METHODS}

An observational, non-therapeutic analytical study was conducted. This is a cross-sectional type of study, involving students from the Faculty of Medical Sciences in order to identify individuals who have fear of blood extraction.

The questionnaire was anonymously filled by students of the Faculty of Medical Sciences: students of medicine, from the study year II - VI; pharmacy, from the study year II - V, dentistry - study year II IV and students of the second study year of basic vocational studies. The introduction contained instructions for completing the questionnaire and the purpose of the questionnaire, as well as questions related to sex, age, the course and year of study. Respondents filled in the questionnaire by ticking off one of the offered answers that best reflected their opinions. The answers were in the form of a sixpoint scale: 0 - completely disagree, 1 - moderately disagree, 2 - slightly disagree, 3 - neither agree nor disagree, 4 - slightly agree, 5 - moderately agree and 6 - completely agree.

Data are processed in IBM SPSS Statistics 21. The parameters showing the reliability of the questionnaire were determined; a mutual correlation between each question, variance and average value of each question were determined, as well as the main parameter for determining the reliability of the questionnaire - Cronbach's Alpha (including the split half parameter). The values of the Cronbach alpha coefficient greater than 0.7 and less than 1 were considered desirable, and the goal, among other things, was to gain value within this reference value. After determining the reliability of the questionnaire, a Kaiser-Meyer-Olkin (KMO) test was also made, which tells us how adequate a sample was in the survey. In the first part of the factor analysis, factor extraction was made, and then all the factors whose value of the Initial Eigenvalue parameter was greater than 1 were taken into consideration. Then, an orthogonal rotation was performed using the Varimax method. By analysing the results obtained through Scree plot graphics, three definitive factors were isolated.

\section{RESULTS}

\section{Socio-demographic characteristics of respondents}

The average age of the respondents was $22 \pm$ 1.61 years. The study included 300 respondents, of which 245 women and 55 men. All respondents were aged from 18 to 22 years (Table 1 ).

Table 1. Distribution of respondents by gender and study program

\begin{tabular}{c|l|c|c|c}
\hline \hline & Study course & Males & Females & Total \% \\
\hline 1. & Students of Medicine & 23 & 73 & 32 \\
\hline 2. & Students of Pharmacy & 23 & 137 & 53 \\
\hline 3. & Students of Dentistry & 5 & 24 & 10 \\
\hline $\begin{array}{l}\text { 4. } \\
\text { Students of basic } \\
\text { vocational studies }\end{array}$ & 4 & 11 & 5 \\
\hline \hline
\end{tabular}

\section{Reliability analysis}

The reliability analysis was aimed at determining to what extent the issues correlate with one another. No question had any negative correlation with any single issue and satisfactory correlation values were obtained, and on the basis of the correlation matrix, it was not necessary to eliminate any question from the questionnaire (Table 2).

The Cronbach's Alpha questionnaire was $\alpha=0.8$. At the beginning, the value was higher $(\alpha=0.9)$, but after the final elimination of the questions (questions $17,18,19$ and 22) this value was reached (Table 3). Questions were eliminated because they were poorly conceived, so it was assumed that respondents responded to them poorly, and therefore the average value was low. 
Table 2. Matrix of the correlation of the questions(1-22)

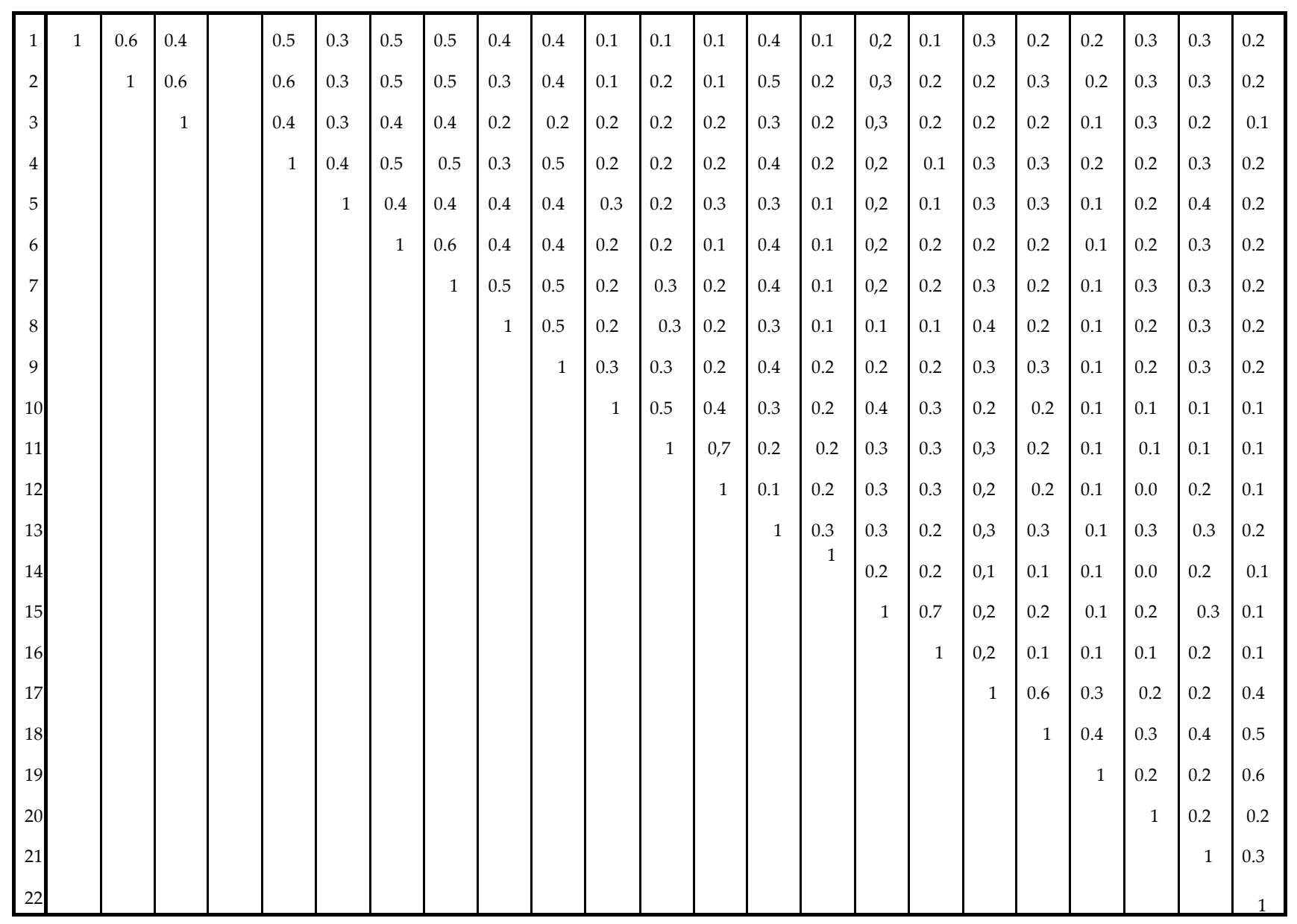

Table 3. Changes in the value of Cronbach's Alpha depending on the eliminated questions

\begin{tabular}{l|c|c|c}
\hline \hline & $\begin{array}{c}\text { Cronbach's } \\
\text { Alpha }\end{array}$ & $\begin{array}{c}\text { Cronbach's Alpha, } \\
\text { Part 1 }\end{array}$ & $\begin{array}{c}\text { Cronbach's Alpha, } \\
\text { Part 2 }\end{array}$ \\
\hline All questions & 0.9 & 0.8 & 0.7 \\
\hline Without question no. 17 & 0.8 & 0.8 & 0.7 \\
\hline Without question no. 17 and18 & 0.8 & 0.8 & 0.7 \\
\hline Without question no. 17,18 and 19 & 0.8 & 0.8 & 0.7 \\
\hline $\begin{array}{l}\text { Without question no. 17, 18, 19 } \\
\text { and 22- final version }\end{array}$ & 0.8 & 0.8 & 0.7 \\
\hline \hline
\end{tabular}

\section{Descriptive statistics}

In addition to determining the correlation of the questions, the variance and the average value for each question, as well as for each factor separately, were determined (Tables 4 and 5). The question number 5 had the lowest variance, 1.5 . The variance for other questions ranged from 2.8 to 4.7. The average values of the questions ranged from 1.6 to 4.5. Although some questions could be eliminated on the basis of statistical data (low mean, < 2), the questionnaire will not include those assertions that could point to respondents who are afraid of blood extraction. 
Table 4. The average value and variance of each question determined by the method of descriptive statistics

\begin{tabular}{c|c|c|c|c}
\hline \hline & $\begin{array}{c}\text { Number of } \\
\text { respondents }\end{array}$ & $\begin{array}{c}\text { Average } \\
\text { value }\end{array}$ & $\begin{array}{c}\text { Standard } \\
\text { deviation }\end{array}$ & Variance \\
\hline Question no. 1 & 300 & 2.8 & 2.1 & 4.3 \\
\hline question no. 2 & 300 & 3.4 & 2.2 & 4.6 \\
\hline question no. 3 & 300 & 3.5 & 2 & 4.3 \\
\hline question no. 4 & 300 & 2.9 & 2.0 & 4.1 \\
\hline question no. 5 & 300 & 1.6 & 1.2 & 1.5 \\
\hline question no. 6 & 300 & 2.8 & 2.0 & 4.3 \\
\hline question no. 7 & 300 & 3 & 2.0 & 4.3 \\
\hline question no. 8 & 300 & 1.9 & 1.6 & 2.8 \\
\hline question no. 9 & 300 & 2.2 & 1.8 & 3.4 \\
\hline question no. 10 & 300 & 2.8 & 2.0 & 4.1 \\
\hline question no. 11 & 300 & 3.3 & 2.0 & 4.1 \\
\hline question no. 12 & 300 & 3.4 & 2.0 & 4.2 \\
\hline question no. 13 & 300 & 3.2 & 2.2 & 5.0 \\
\hline question no. 14 & 300 & 3.7 & 2.2 & 5.2 \\
\hline question no. 15 & 300 & 4.2 & 2.0 & 4.1 \\
\hline question no. 16 & 300 & 4.4 & 1.9 & 3.7 \\
\hline question no. 17 & 300 & 1.8 & 1.7 & 2.9 \\
\hline question no. 18 & 300 & 1.7 & 1.5 & 2.2 \\
\hline question no. 19 & 300 & 2.4 & 2.0 & 4.3 \\
\hline question no. 20 & 300 & 4.0 & 2.1 & 4.6 \\
\hline question no. 21 & 300 & 2.2 & 1.8 & 3.4 \\
\hline question no. 22 & 300 & 1.8 & 1.6 & 2.6 \\
\hline \hline
\end{tabular}

Table 5. Factor values and total score determined by the method of descriptive statistics

\begin{tabular}{l|c|c|c|c|c}
\hline \hline & $\begin{array}{c}\text { Number of } \\
\text { respondent }\end{array}$ & Minimum & Maximum & $\begin{array}{c}\text { Average } \\
\text { value }\end{array}$ & $\begin{array}{c}\text { Standard } \\
\text { deviation }\end{array}$ \\
\hline Factor 1 & 300 & 12 & 81 & 33.6 & 16.1 \\
\hline Factor 2 & 300 & 3 & 21 & 9.6 & 5.1 \\
\hline Factor 3 & 300 & 3 & 21 & 12.5 & 4.8 \\
\hline Total & 300 & 20 & 121 & 55.7 & 21.6 \\
\hline \hline
\end{tabular}

\section{Factor Analysis}

In order to determine the number of factors that this questionnaire examined and to structure the questionnaire, an exploratory factor analysis was done. After extraction of factors, based on the value of the Eigen value parameter, four factors stood out that had the value of the parameter above 1 .
After the elimination of the questions that did not fit into the questionnaire $(17,18,19,22)$, the extraction of the factor and the rotational matrix by the Varimax method was done again, and the questions were classified into the final 3 groups (Tables 6 and $7)$. The factors were named on the basis of the claims they included, so Factor 1 was called the "Vasovagal 
Table 6. Values of the KMO and Bartlett's test of significance

\begin{tabular}{lcc}
\hline \hline Kaiser-Meyer-Olkin Measure of Sampling Adequacy & .875 \\
\hline Bartlett'sTest of Sphericity & Approx.Chi-Square & 2463.2 \\
\hline & $\mathrm{df}$ & 153 \\
\hline & $\mathrm{Sig}$. & .000 \\
\hline \hline
\end{tabular}

Table 7. Display of factors depending on the Eigenvalue

\begin{tabular}{|c|c|c|c|c|c|c|c|c|c|}
\hline \multirow{2}{*}{$\begin{array}{l}\vec{Z} \\
\mathbb{0} \\
0 \\
\text { Z } \\
0 \\
0\end{array}$} & \multicolumn{3}{|c|}{$\begin{array}{l}\text { The initial values of the } \\
\text { Eigenvalue parameter }\end{array}$} & \multicolumn{3}{|c|}{$\begin{array}{l}\text { Values of the Eigenvalue } \\
\text { parameter after extraction }\end{array}$} & \multicolumn{3}{|c|}{$\begin{array}{l}\text { Values of the Eigenvalue } \\
\text { parameter after rotation }\end{array}$} \\
\hline & Total & $\begin{array}{l}\text { Pecentage } \\
\text { of variance }\end{array}$ & $\begin{array}{l}\text { Cumulative } \\
\text { percentage }\end{array}$ & Total & $\begin{array}{l}\text { Pecentage } \\
\text { of variance }\end{array}$ & $\begin{array}{l}\text { Cumulative } \\
\text { percentage }\end{array}$ & Total & $\begin{array}{l}\text { Pecentage } \\
\text { of variance }\end{array}$ & $\begin{array}{l}\text { Cumulative } \\
\text { percentage }\end{array}$ \\
\hline 1 & 6.6 & 36.5 & 37.1 & 6.6 & 37.1 & 37.1 & 5.2 & 29.2 & 29.2 \\
\hline 2 & 2.1 & 11.0 & 48.7 & 2.1 & 11.6 & 48.7 & 2.5 & 14.3 & 43.6 \\
\hline 3 & 1.3 & 7.1 & 56.1 & 1.3 & 7.4 & 56.1 & 2.2 & 12.5 & 56.1 \\
\hline 4 & 0.9 & 5.3 & 61.5 & & & & & & \\
\hline 5 & 0.9 & 5.1 & 66.6 & & & & & & \\
\hline 6 & 0.8 & 4.8 & 71.5 & & & & & & \\
\hline 7 & 0.7 & 4.2 & 75.7 & & & & & & \\
\hline 8 & 0.6 & 3.6 & 79.3 & & & & & & \\
\hline 9 & 0.5 & 3.0 & 82.4 & & & & & & \\
\hline 10 & 0.4 & 2.6 & 85.1 & & & & & & \\
\hline 11 & 0.4 & 2.6 & 87.6 & & & & & & \\
\hline 12 & 0.4 & 2.5 & 90.2 & & & & & & \\
\hline 13 & 0.4 & 2.3 & 92.5 & & & & & & \\
\hline 14 & 0.3 & 1.8 & 94.4 & & & & & & \\
\hline 15 & 0.3 & 1.7 & 96.1 & & & & & & \\
\hline 16 & 0.2 & 1.4 & 97.6 & & & & & & \\
\hline 17 & 0.2 & 1.2 & 98.5 & & & & & & \\
\hline 18 & 0.2 & 1.1 & 100 & & & & & & \\
\hline
\end{tabular}

Symptoms", as it includes claims related to the activation of the autonomic nervous system as a consequence of phobia. Factor 2 was named "Fear of the needle and the consequences of the puncture", which would be the possible consequences of needle sticking, which can be a cause of fear of blood extraction. Factor 3 was named "Fear of the hospital and the person who extracts the blood" because the claims relate to the fear of going to the hospital and the staff of the hospital who perform blood extraction (Table 8).

The value of the Kaiser-Meyer-Olkin parameter (KMO) was 0.875, which is considered as high values of this coefficient. The values of the Bartlett test show that there was a statistical significance of the questionnaire (excluding eliminated questions) because $\mathrm{p}<0.05$. 
Table 8. Distribution of questions by factors after rotation by Varimax method10

\begin{tabular}{l|c|c|c}
\hline \multirow{2}{*}{} & \multicolumn{3}{|c}{ Factors } \\
\cline { 2 - 4 } & 1 & 2 & 3 \\
\hline Question 1 & 0.7 & -0.0 & 0.1 \\
\hline Question 2 & 0.7 & -0.0 & 0.3 \\
\hline Question 3 & 0.5 & -0.0 & 0.4 \\
\hline Question 4 & 0.7 & 0.1 & 0.1 \\
\hline Question 5 & 0.5 & 0.4 & -0.0 \\
\hline Question 6 & 0.7 & 0.1 & 0.1 \\
\hline Question 7 & 0.7 & 0.2 & 0.1 \\
\hline Question 8 & 0.6 & 0.4 & -0.1 \\
\hline Question 9 & 0.6 & 0.4 & -0.0 \\
\hline Question 10 & 0.1 & 0.7 & 0.2 \\
\hline Question 11 & 0.1 & 0.8 & 0.3 \\
\hline Question 12 & 0.1 & 0.7 & 0.2 \\
\hline Question 13 & 0.6 & 0.1 & 0.2 \\
\hline Question 14 & 0.1 & 0.2 & 0.4 \\
\hline Question 15 & 0.1 & 0.2 & 0.8 \\
\hline Question 16 & 0.1 & 0.2 & 0.7 \\
\hline Question 20 & 0.4 & -0.1 & 0.2 \\
\hline Question 21 & 0.5 & 0.2 & 0.1 \\
\hline \hline
\end{tabular}

\section{Eliminated questions:}

17. I avoid visiting a doctor if I think there is a possibility for blood tests.

18. In order to avoid blood extraction, I mention some obligation as an excuse.

19. The only good reason for blood extraction would be serious issues with my health condition.

22. I would wait for my health conditions to become really serious before I undergo blood extraction for any medical reason.

Screeplot shows the dependence of the Eigenvalue parameter on the number of factors, in a descending order, relative to the number of questions that belong to that factor (Figure 1).

Factor 1: Vasovagal symptoms

1. When I have blood extraction, I have the feeling that I will faint.

2. I feel tense when I see a needle.

3. The size of the needle that is used for blood extraction scares me.

4. My heart is beating faster when I see blood.

5. I feel a strong headache before blood extraction.

6. I have the urge to vomit before and/or after blood extraction.

7. I feel nauseous when I see a tube with my blood.

8. My hands are sweating before I get into the room where blood is to be extracted.

9. Before blood extraction, my breathing is getting faster.

13. I'm afraid of blood extraction from my finger and/or vein.

20. I wish there was another way to analyse blood, without performing blood extraction.

21. Whenever I need to have blood extraction, I go with some family member/friend because I'm afraid to go alone.

Factor 2: Fear of the needle and the consequences of the needle stick

10. I'm afraid that after the blood extraction, hematoma will appear at the puncture site.

11. I'm afraid the needles used for blood extraction are not sterile.

12. I am afraid that during the extraction I would become infected with hepatitis, HIV or similar diseases.

Factor 3: Fear of a hospitals and a person who extracts the blood (the fact is related to fear of going to the hospital and hospital staff in charge of extracting blood)

14. Hospital smell makes me sick.

15. I'm afraid the person who extracts my blood will miss my vein.

16. I'm afraid that the person who will extract my blood may be incompetent. 


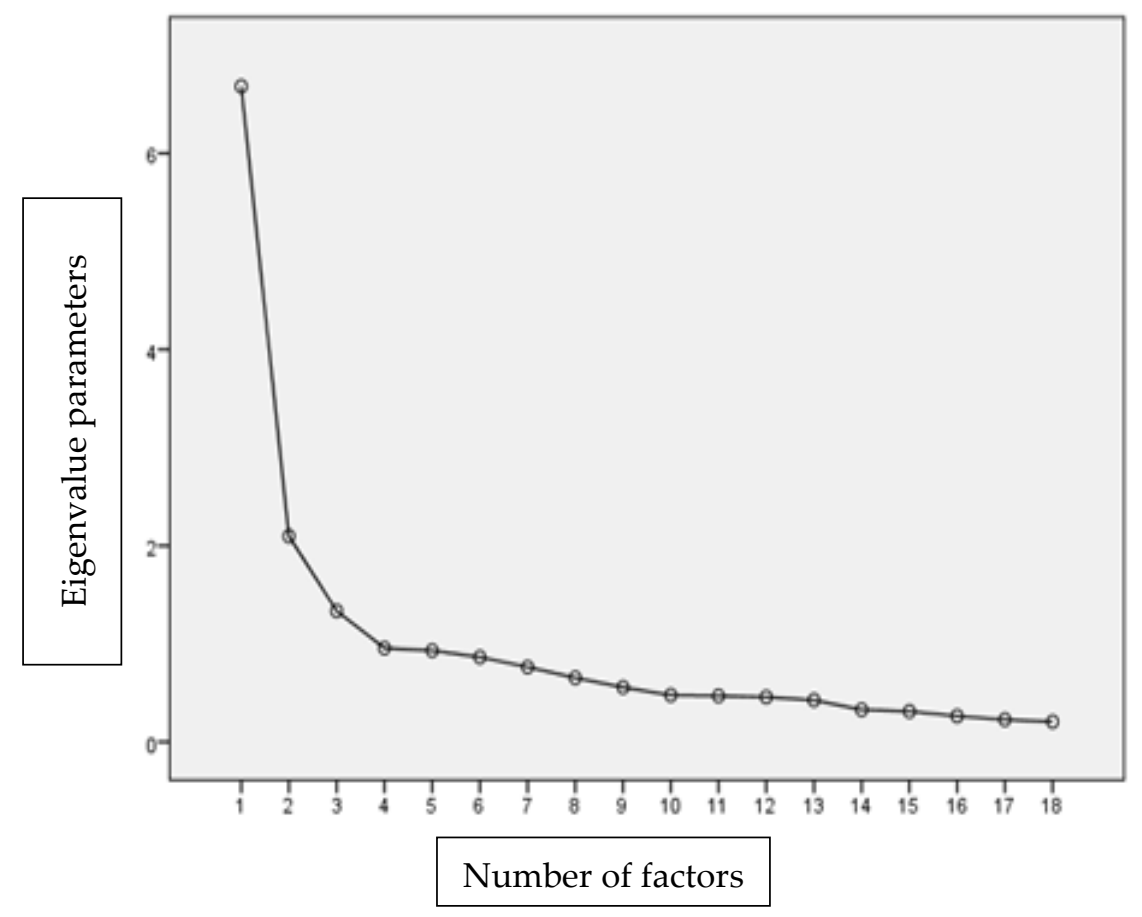

Figure 1. Display of factors depending on the Eigenvalue value

\section{DISCUSSION}

Based on the obtained statistical results, among which the most significant parameter is the value of the Cronbach alpha coefficient, the value of which for this questionnaire is 0.894 , a high degree of reliability of this questionnaire is shown. Within the questionnaire, three factors were used to determine the frequency of the phenomenon:

1. Vasovagal symptoms; 2. Fear of needle and consequences of needle stick; and 3. Fear of hospital and person extracting the blood. As already mentioned, factor 1 covers the claims related to the symptoms of the activation of the autonomic nervous system as a result of fear of needle and/or blood; factor 2 is related to the fear of the needle and the consequences of the needle stick, while factor 3 includes issues related to the fear of the hospital and professionalism and qualifications of the person who performs blood extraction.

The study "The mutilation questionnaire as a predictor of blood/injury fear and fainting", which examined the reliability of a questionnaire on a similar topic, was conducted on two groups of students (the first group included 803 and the other one 204 students). The study included the use of three different questionnaires to identify students who experienced the loss of consciousness in situations in- volving blood and needles, or fear of sharp objects, human and animal blood and dead bodies. Questions were classified into two parts - disgust from blood, injuries and mutilation, and fear of physical injury, although the values of the exploratory analysis indicated a number of factors (2).

Fear of needles and vasovagal reactions among phlebotomy patients, included 3,315 respondents, with an average age of 57 years, to whom at least once during the study blood was extracted. They filled in a questionnaire consisting of 14 questions, immediately after blood extraction and containing two sets of questions. The first one were related to the symptoms that the respondents felt during the last blood extraction, to anxiety and disturbance of consciousness, using a scale of five offered responses. The second group of questions referred to a psychological reaction, vasovagal symptoms and fear of needles. The disadvantage of this study is that the questions are solely related to patients who have already been diagnosed with phobia, thus reducing the ability to evaluate the reliability of the questionnaire to diagnose this phobia (9).

The study "The blood-injection symptom scale" (biss): the assessment of the structure of phobic symptoms elicited by blood and injections involved 605 students of psychology, an average of 19 years of age and an exploratory factor analysis of 
three factors related to the symptoms that occurred with this phobia: nausea, anxiety and tension. They all relate to the symptoms that respondents could experience during blood extraction, and do not include issues related to the fear of needles, hospital, or staff doing the blood extraction. As mentioned in the introduction, the reliability of this questionnaire is $\alpha=0.86$. The disadvantage of this questionnaire is that there were only two offered answers - yes and no, and it was impossible to include all respondents with this phobia (7).

A study conducted in Spain (Blood-Injection Phobia Inventory (BIPI): Development, Reliability and Validity) included 39 patients aged between 15 and 30 years, who according to the DSM-IV classification were diagnosed with blood and needle fear, as a specific phobia no other phobias or anxiety disorder with detected; the control group consisted of 137 respondents from the general population. Fear Questionnaire, which was used in this study, was designed to measure agoraphobia, social phobia and BII phobia, and consists of two parts (the first one refers to the degree to which people avoid certain situations and events related to the mentioned phenomena, and offered responses in the form of the Likert scale; the second part of the questionnaire refers to their concern with the presence of symptoms of anxiety, fear and depression. This study has three factors: a cognitive, psychological, and behavioural response to fear. This questionnaire shows high reliability (values of the entire questionnaire $\alpha=$ 0.7 ; BII phobia $-\alpha=0.7$; social phobia $-\alpha=0.6$; agoraphobia $-\alpha=0.5$ ). Compared to previous studies, this has a greater advantage and significance, and the best approach is to measure the investigated phenomenon in the control and experimental group. The disadvantage of this study is the size of the test sample, and a slightly lower Cronbach's alpha pa- rameter value (10). The biggest difference in relation to the existing questionnaires is that they all involve phobias from blood, needles and injuries, so the questions in these questionnaires are directed at all situations involving the mentioned phenomena, but not exclusively related to the fear of blood extraction.

\section{Limitations of the study}

The disadvantage of this questionnaire is that few questions belong to factors 2 and 3 (3 questions for each), and it should be corrected in the future research. Factor 1 also includes questions that are not related to the measurement of this phenomenon (question No. 20 and 21), and they should exist as a special factor. Questions that had to be eliminated should have been better formulated before the questionnaire was compiled, and there should also be a fourth factor to examine the avoidance of blood extraction and a visit to a doctor, to which the aforementioned questions (20 and 21) should belong and which would better identify individuals who are afraid of blood extraction.

\section{CONCLUSION}

In order to design a questionnaire which examines the factors that lead to fear of blood extraction in patients, questions should focus on symptoms that may arise as a result of contact with the needle, blood, the hospital, and blood-extraction personnel. This questionnaire was an attempt to cover the listed phenomena, and in this way identify those who have this phobia. Although statistical parameters show the high reliability of the existing questionnaires, future research should pay attention to the number of factors that are measured, which are directly related to the mentioned phobia. 


\section{References}

1. Bienvenu OJ, Eaton WW. The epidemiology of blood injection injuryphobia.

Psychol Med 1998;28(5): 1129-36.

https://doi.org/10.1017/S0033291798007144

2. Kleinknecht RA,Thorndike RM. The Mutilation Questionnaire as a predictor of blood/injury fear and fainting. Behav Res Ther 1990;28(5):429-37. https://doi.org/10.1016/0005-7967(90)90163-D

3. Chapman L K, De LappR. Nine Session Treatment of a Blood-Injection-Injury Phobia With Manualized Cognitive Behavioral Therapy: An Adult Case Example. Clin Case Stud 2014;13(4):299-312. https://doi.org/10.1177/1534650113509304

4. Ducasse D, Capdevielle D, Attal J, et al. Bloodinjection-injuryphobia: Physochophysiological and therapeutical specificities. Encephale 2013; 39(5):326-31. [Article in French] https://doi.org/10.1016/j.encep.2012.06.031

5. Engel, G. Psychologic stress, vasodepressor (vasovagal) syncope and sudden death. Ann Intern Med 1978; 89(3):403-12.

https://doi.org/10.7326/0003-4819-89-3-403
6. Graham, D. Prediction of faint in ginblo oddonors. Circulation 1961;23:901-6.

https://doi.org/10.1161/01.CIR.23.6.901

7. Page AC, Bennett KS, Carter O, et al. The BloodInjection Symptom Scale (BISS): assessing a structure of phobic symptoms elicited by blood and injections. Behav Res Ther.1997; 35(5):457-64. https://doi.org/10.1016/S0005-7967(96)00120-9

8. WaniAL,Ara A,Bhat SA. Blood Injury and Injection Phobia: The Neglected One. Behav Neurol 2014; 2014: 471340.

https://doi.org/10.1155/2014/471340

9. Deacon B, Abramowitz J. Fearof needles andvasovagalreactions amongphlebotomy patients. J Anxiety Disord 2006;20(7):946-60. https://doi.org/10.1016/j.janxdis.2006.01.004

10. Borda Mas M, López Jiménez AM, Ángeles Pérez, San Gregorio M. Blood-injection Phobia Inventory (BIPI): Development, reliability and validity. An Psicol 2010;26(1):58-71. 


\title{
Izrada i ispitivanje pouzdanosti upitnika o strahu od vađenja krvi kod studenata fakulteta medicinskih nauka
}

\author{
Suzana Milutinović 1 , Ana Stanković², Sunčica Ivanović ${ }^{1}$, Sanja Trgovčević ${ }^{1}$, Tatjana Kilibarda ${ }^{1}$ \\ ${ }^{1}$ Akademija vaspitačko-medicinskih strukovnih studija Kruševac-Odsek Ćuprija, Ćuprija, Srbija \\ ${ }^{2}$ Fakultet medicinskih nauka Univerziteta u Kragujevcu, Kragujevac, Srbija
}

\section{SAŽETAK}

Korišćenje validiranih upitnika o strahu od igle i vađenja krvi od posebnog je značaja, jer je ovaj javni zdravstveni problem primećen kod velikog broja bolesnika i može da utiče na neadekvatno pružanje medicinske pomoći.

Ispitivanje pouzdanosti upitnika o strahu od vađenja krvi kod studenata sprovedeno je na Fakultetu medicinskih nauka Univerziteta u Kragujevcu.

U ovom istraživanju korišćena je studija preseka. Uzorak su činili studenti Fakulteta medicinskih nauka Univerziteta u Kragujevcu, ukupno njih 300, što čini $20 \%$ populacije studenata na pomenutom fakultetu. Instrument istraživanja bio je upitnik The Blood-Injection Symptom Scale (BISS), koji se sastojao od 22 pitanja. Istraživanje je obavljeno u toku jednog meseca 2016. godine. Statistička obrada podataka izvršena je korišćenjem programa IBM SPSS Statistics 21.

Na osnovu vrednosti parametra Cronbach's Alpha $(0,894)$ i drugih parametara, koji su korišćeni u cilju određivanja pouzdanosti, pokazan je visok stepen pouzdanosti ovog upitnika. Nakon izvršene eksplorativne faktorske analize, dobijena su tri faktora, koja najviše utiču na nepovoljne ishode kod venepunkcije - vazovagalni simptomi, prisutan strah od igle i posledica uboda, kao i prisutan strah od bolnice i osobe koja uzima krv.

Upitnik BISS pokazao je dobru pouzdanost na populaciji studenata Fakulteta medicinskih nauka Univerziteta u Kragujevcu i može se primeniti na opštoj populaciji za ispitivanje straha od igle, posledica uboda, straha od bolnice i osoba koje uzimaju krv, a samim tim i za prevenciju ovih simptoma.

Ključne reči: upitnik, pouzdanost, strah od igle i vađenja krvi 